\title{
Efek Antibakteri Ekstrak Etanol Daun Kelor (Moringa oleifera Lam.) dan Sediaan Masker Gel Peel-Off Ekstrak Etanol Daun Kelor (Moringa oleifera Lam.)
}

\author{
Theresia H. Tunas*,Hosea Jaya Edy*,Jainer Pasca Siampa* \\ Program studi Farmasi, Fakultas Matematika dan IImu Pengetahuan Alam, \\ Universitas Sam Ratulangi Manado
}

\begin{tabular}{l} 
K A T A K U N C I \\
\hline Daun Kelor (Moringa oleifera \\
Lam.) \\
Masker gel peel-off \\
Antibakteri \\
Staphylococcus aureus
\end{tabular}

Kelor leaf

Peel-off mask

Antibacterial,

Staphylococcus aureus
KEYWOR D S

\begin{abstract}
A B S T R A K
Daun Kelor (Moringa oleifera Lam.) bermanfaat untuk menghambat aktivitas pertumbuhan bakteri karena adanya kandungan senyawa flavonoid, alkaloid, dan fenol. Penelitian ini bertujuan untuk menguji aktivitas antibakteri dari ekstrak etanol daun Kelor dan sediaan masker gel peel-off ekstrak etanol daun Kelor terhadap bakteri Staphylococcus aureus. Penelitian ini menggunakan metode eksperimental laboratorium, ekstrak etanol daun kelor dan sediaan masker gel peel-off ekstrak etanol daun Kelor dibuat dengan konsentrasi 1, 3, 5, 7, dan 9\%. Ekstrak daun Kelor diperoleh dengan cara maserasi dengan menggunakan pelarut etanol 96\%. Pada pengujian antibakteri menggunakan metode sumuran. Diameter zona hambat paling besar yang ditimbulkan oleh ekstrak etanol daun Kelor yaitu pada konsentrasi $7 \%$ dengan diameter zona hambat sebesar 5,75 mm, sedangkan pada sediaan masker gel peel-off tidak menunjukkan adanya daya hambat. Dapat disimpulkan bahwa ekstrak etanol daun Kelor memiliki aktivitas antibakteri yang termasuk dalam kategori sedang.

A B S T R A C T
Moringa oleifera Lam. (Moringa oleifera) leaves are useful for inhibiting
bacterial growth activity due to the presence of flavonoid, alkaloid, and
phenol compounds. This study aims to test the antibacterial activity of the
Moringa leaf ethanol extract and the gel peel-off mask preparation of
Moringa leaf ethanol extract against Staphylococcus aureus bacteria. This
study uses laboratory experimental methods, Moringa leaf ethanol extract
and gel mask peel-off preparation for Moringa leaf ethanol extract made
with concentrations of $1,3,5,7$, and $9 \%$. Moringa leaf extract was
obtained by maceration using $96 \%$ ethanol solvent. In antibacterial testing
using the well method. The biggest inhibition zone diameter caused by
ethanol extract of Moringa leaves is at a concentration of $7 \%$ with a
inhibition zone diameter of 5.75 mm, whereas the peel-off gel mask
preparation did not show any inhibitory power. It can be concluded that the
ethanol extract of Moringa leaves has antibacterial activity which is
included in the medium category.
\end{abstract}

TERSEDIA ONLINE

31 Okotober 2019

\section{Pendahuluan}

Seiring berjalannya waktu, pengetahuan tentang tumbuhan obat semakin berkembang. Masyarakat saat ini lebih memilih menggunakan obat dari alam karena banyaknya kendala yang ditimbulkan oleh penggunaan obat sintesis, seperti harganya mahal dan kesadaran akan timbulnya resistensi bakteri. Agar masyarakat merasa aman menggunakan bahan alam sebagai bahan obat maka perlu dilakukan pengujian keamanan dan aktivitas dari zat aktif tersebut. Bahan alam yang telah diuji

*Corresponding author: Program Studi Farmasi, Fakultas MIPA, Universitas Sam Ratulangi, Manado.

Email address: theresia15.hana@gmail.com

Published by FMIPA UNSRAT (2019) 
keamanannya dan dibuat dalam bentuk sediaan farmasi akan mempermudah pemanfaatannya dalam proses terapi (Edy dan Parwanto, 2019).

Daun Kelor merupakan salah satu tumbuhan yang dapat digunakan sebagai sediaan farmasi yang berkhasiat sebagai antibakteri. Daun Kelor berbentuk bulat telur, bersirip tak sempurna, beranak daun gasal, dan tersusun majemuk dalam satu tangkai. Helaian daun kelor berwarna hijau, ujung daun tumpul, pangkal daun membulat, tepi daun rata, susunan pertulangan menyirip dan memiliki ukuran 1-2 cm (Yulianti, 2008).

Kandungan senyawa seperti flavonoid, saponin dan tannin yang ada dalam daun kelor berperan sebagai senyawa yang dapat menghambat pertumbuhan aktivitas antibakteri (Moyo et al., 2012).

Masker gel peel-off merupakan salah satu sediaan masker yang praktis dalam penggunaannya karena setelah kering masker tersebut bisa langsung diangkat tanpa harus dibilas dengan air. Salah satu keuntungan dari masker gel peel-off yaitu dapat mengangkat kotoran dari sel kulit mati hingga kulit bersih dan segar. Cara kerja dari masker gel peel-off ini yaitu saat dilepaskan, kotoran dan kulit ari yang telah mati akan ikut terangkat (Basuki, 2001).

Bakteri Staphylococcus aureus merupakan bakteri gram positif berbentuk bulat dan berdiameter 0,7-1,2 $\mu \mathrm{m}$. Bakteri ini merupakan jenis bakteri yang paling kuat daya tahannya berdasarkan bakteri yang tidak membentuk spora. Staphylococcus aureus dapat tetap hidup selama 6-14 minggu dalam keadaan kering pada benang, kertas, kain dan dalam nanah (Syahrurachman et al., 1994).

\section{Material dan Metode \\ Bahan dan alat}

Daun Kelor, etanol 96\%, PVA, HPMC, propilen glikol, TEA, aquadest, Nutrient Agar (NA), larutan Mc. Farland, Ciprofloxacin 500mg, bakteri Staphylococcus aureus, alat-alat gelas, rotary evaporator, autoclave, oven, timbangan analitik, blender, hot plate, incubator, pipet mikro.

\section{Ekstraksi}

Daun Kelor diambil di Kota Manado di Kecamatan Kairagi 1 dan kemudian di identifikasi kebenaran tumbuhan di Laboratorium Biologi Fakultas Matematika dan IImu Pengetahuan Alam, Universitas Sam Ratulangi Manado. Daun Kelor dicuci bersih dengan air mengalir kemudian ditiriskan. Setelah itu ditimbang dan dikeringnkan dalam oven yang selanjutnya dibuat simplisia. Simplisia yang telah kering kemudian diblender menjadi serbuk kasar lalu diayak dengan ayakan dan selanjutnya dilakukan proses ekstraksi.

Pembuatan ekstrak daun Kelor menggunakan teknik remaserasi atau maserasi berulang. Teknik remaserasi dipilih agar mendapatkan ekstrak yang lebih banyak dimana seluruh zat aktif yang ada dalam sampel dapat tersari sempurna. Penggantian jenis pelarut yang sama dalam setiap proses remaserasi bertujuan untuk menghindari terjadinya kejenuhan saat proses penyarian (Edy et al., 2016). Serbuk daun kelor sebanyak 400 gram direndam menggunakan pelarut etanol 96\% sebanyak 1600 $\mathrm{mL}$ dibiarkan selama 3 hari sambal sesekali diaduk. Setelah 3 hari disaring dengan kertas saring dan menghasilkan filtrate dan residu. Residu yang ada kemudian diremaserasi menggunakan jenis dan jumlah pelarut yang sama selama 2 hari. Setelah 2 hari, sampel disaring sehingga menghasilkan filtrate 2 dan residu 2. Filtrate 1 dan 2 digabung dan dievaporasi menggunakan rotary evaporator sehingga diperoleh ekstrak kental.

\section{Formulasi}

Formulasi sediaan masker gel peel-off ekstrak etanol daun kelor dengan variasi senyawa aktif dapat dilihat pada tabel1.

Tabel 1 Modifikasi dari Edy et al., (2017).

\begin{tabular}{|c|c|c|c|c|c|}
\hline \multirow[t]{2}{*}{ Bahan } & \multicolumn{5}{|c|}{ Konsentrasi (\%b/v) } \\
\hline & F1 & F2 & F3 & F4 & F5 \\
\hline $\begin{array}{l}\text { Ekstrak daun } \\
\text { Kelor }\end{array}$ & 1 & 3 & 5 & 7 & 9 \\
\hline PVA & 9 & 9 & 9 & 9 & 9 \\
\hline HPMC & 1 & 1 & 1 & 1 & 1 \\
\hline Propilenglikol & 10 & 10 & 10 & 10 & 10 \\
\hline TEA & 0,15 & 0,15 & 0,15 & 0,15 & 0,15 \\
\hline Aquadest & $\begin{array}{c}\text { ad } \\
100 \\
m L\end{array}$ & $\begin{array}{c}\text { ad } \\
100 \\
m L\end{array}$ & $\begin{array}{c}\text { ad } \\
100 \\
m L\end{array}$ & $\begin{array}{c}\mathrm{ad} \\
100 \\
\mathrm{~mL}\end{array}$ & $\begin{array}{c}\text { ad } \\
100 \\
m L\end{array}$ \\
\hline
\end{tabular}

Pembuatan sediaan masker wajah peel-off dimulai dengan HPMC dilarutkan dalam aquadest dingin \pm 24 jam hingga mengembang sempurna. PVA dimasukkan dalam beaker yang telah dipanaskan air panas dengan suhu $80^{\circ} \mathrm{C}$ di atas hot plate diaduk sampai homogen. Kemudian ditambahkan propilenglikol, HPMC dan TEA secara berturut-turut ke dalam massa PVA dan diaduk sampai homogen dengan menggunakan mixer. Selanjutnya basis sediaan masker peel-off disterilkan dalam autoklaf pada suhu $121^{\circ} \mathrm{C}$ dengan tekanan 1 atm selama 15 menit kemudian ditambahkan ekstrak daun Kelor yang telah diencerkan dengan aquadest selanjutnya diaduk hingga homogen. Setelah sediaan dibuat dalam 5 konsentrasi kemudian masing-masing sediaan di uji efektivitas antibakterinya.

\section{Sterilisasi Alat dan Bahan}

Semua peralatan gelas yang akan digunakan dicuci bersih, dikeringkan, kemudian dibungkus dengan menggunakan alumunium foil dan disterilkan dalam autoklaf pada suhu $121^{\circ} \mathrm{C}$ selama 15 menit. Kawat ose dibakar dengan lampu spritus sampai memijar.

\section{Pengujian aktivitas dan efektivitas antibakteri}

Media uji dibuat dengan metode difusi agar dengan cara sumuran dengan 2 lapisan media agar. Larutan uji ekstrak daun Kelor dengan konsentrasi 
1, 3, 5, 7 dan 9\% dimasukkan pada sumur-sumur yang berbeda sebanyak 50 $\mathrm{ll}$ menggunakan mikropipet dan bahan uji masker peel-off ekstrak daun Kelor dengan konsentrasi 1, 3, 5, 7 dan 9\% dimasukkan pada sumur-sumur yang berbeda sebanyak 0,1 gram menggunakan sudip.

Aquadest digunakan sebagai kontrol negatif dimasukkan pada sumur-sumur sebanyak 50 $\mathrm{\mu l}$ menggunakan mikropipet dan basis gel masker digunakan sebagai kontrol negatif dimasukkan pada sumur-sumur sebanyak 0,1 gram menggunakan sudip.

Tablet Ciprofloxacin yang telah dilarutkan dalam aquadest sebagai control positif dimasukkan pada

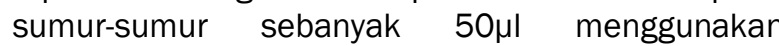
mikropipet dan gel spot Acnes digunakan sebagai kontrol positif dimasukkan pada sumur- sumur sebanyak 0,1 gram menggunakan sudip.

Kemudian cawan petri diinkubasi dalam inkubator pada suhu $37^{\circ} \mathrm{C}$ selama 24 jam.

\section{Pengamatan dan Pengukuran}

Pengamatan dilakukan setelah $1 \times 24$ jam masa inkubasi. Daerah bening merupakan petunjuk kepekaan bakteri terhadap antibiotik atau bahan antibakteri lainnya yang digunakan sebagai bahan uji yang dinyatakan dengan lebar diameter zona hambat. Diameter zona hambat diukur dalam satuan millimeter ( $\mathrm{mm})$ menggunakan mistar berskala dengan cara diameter keseluruhan dikurangi diameter sumuran $7 \mathrm{~mm}$. Selanjutnya diameter zona hambat tersebut, dihitung kekuatan daya antibakterinya sesuai dengan kriteria kekuatan daya antibakteri menurut Davis and Stout (1971).

\section{Hasil dan Pembahasan}

Hasil identifikasi tanaman yang dilakukan di Laboratorium Biologi Fakultas Matematika dan IImu Pengetahuan Alam, Universitas Sam Ratulangi Manado menunjukkan kebenaran dari tanaman yang digunakan sebagai sampel. Proses ekstraksi yang dilakukan dengan metode maserasi dengan menggunakan pelarut etanol 96\%. Pemilihan etanol 96\% sebagai pelarut dikarenakan pelarut ini lebih selektif, tidak toksik, absorbsinya baik serta dapat mencegah tumbuhnya mikroorganisme. Selain itu pelarut ini bersifat universal sehingga senyawa metabolit polar, semi polar dan non polar dapat tersari dengan sempurna.

Ekstrak kental daun kelor yang diperoleh saat proses maserasi yaitu sebanyak 72,48 gram. Sebanyak 7,5 gram ekstrak daun kelor digunakan untuk pengujian aktivitas antibakteri dan sebanyak 25 gram ekstrak daun kelor digunakan sebagai senyawa aktif dalam pembuatan sediaan masker gel peel-off dengan variasi konsentrasi dan kemudian diuji efektivitas antibakterinya.

Hasil pengujian aktivitas antibakteri ekstrak etanol daun kelor dapat dilihat pada tabel 2.
Tabel 2. Pengujian aktivitas antibakteri ekstrak etanol daun kelor

\begin{tabular}{ccccc}
\hline Konsentrasi & \multicolumn{4}{c}{ Diameter zona Hambat (mm) } \\
\cline { 2 - 5 } & $\begin{array}{c}\text { Pengulangan } \\
\text { I }\end{array}$ & $\begin{array}{c}\text { Pengulangan } \\
\text { II }\end{array}$ & $\begin{array}{c}\text { Pengulangan } \\
\text { III }\end{array}$ & Rata-rata \\
\hline $\mathrm{K}(-)$ & 0 & 0 & 0 & 0 \\
$\mathrm{~K}(+)$ & 10 & 10,25 & 10 & 10,08 \\
$1 \%$ & 0,5 & 0,5 & 0,5 & 0,5 \\
$3 \%$ & 1 & 1,25 & 1 & 1,08 \\
$5 \%$ & 1,5 & 1,5 & 1,75 & 1,58 \\
$7 \%$ & 7,25 & 4,75 & 5,25 & 5,75 \\
$9 \%$ & 2 & 1,75 & 1,75 & 1,83
\end{tabular}

Hasil pengujian efektivitas antibakteri sediaan masker gel peel-off ekstrak etanol daun kelor dapat dilihat pada tabel 3 .

Tabel 3. Pengujian Efektivitas Antibakteri

\begin{tabular}{ccccc}
\hline Formulasi & \multicolumn{4}{c}{ Diameter zona Hambat (mm) } \\
\cline { 2 - 5 } & Pengulangan I & Pengulangan II & Pengulangan III & Rata-rata \\
\hline K(-) & 0 & 0 & 0 & 0 \\
K(+) & 2,5 & 3,25 & 3,25 & 3 \\
F1 (1\%) & 0 & 0 & 0 & 0 \\
F2 (3\%) & 0 & 0 & 0 & 0 \\
F3 (5\%) & 0 & 0 & 0 & 0 \\
F4 (7\%) & 0 & 0 & 0 & 0 \\
F5 (9\%) & 0 & 0 & 0 & 0 \\
\hline
\end{tabular}

Hasil dari pengujian aktivitas antibakteri ekstrak daun kelor dengan konsentrasi 1, 3, 5, 7, dan 9\% didapatkan hasil daya hambatnya terhadap bakteri Staphylococcus aureus yang paling maksimal ditunjukkan pada konsentrasi $7 \%$ dimana besar diameter daya hambatnya yaitu $5,75 \mathrm{~mm}$ yang tergolong sedang.

Pada pengujian efektivitas antibakteri dari sediaan masker gel peel-off ekstrak daun kelor, didapatkan hasil tidak adanya daya hambat terhadap bakteri, didapatkan hasil tidak adanya daya hambat terhadap bakteri Staphylococcus aureus yang ditunjukkan dari beberapa variasi konsentrasi ekstrak dalam sediaan yang digunakan. Menurut Andaryekti et al., 2015, semakin besar viskositas dari basis yang digunakan dalam sediaan, maka akan semakin besar pula kemampuan mengikat dengan ekstrak yang menyebabkan zona hambat yang dihasilkan semakin kecil. Hal ini lah yang menyebabkan tidak adanya daya hambat yang dihasilkan dari sediaan masker gel peel-off. Selain itu penggunaan konsentrasi ekstrak dalam sediaan yang kecil juga berpengaruh pada daya hambat yang ditimbulkan.

\section{Kesimpulan}

Ekstrak etanol daun kelor (Moringa oleifera Lam) memiliki aktivitas antibakteri terhadap bakteri Staphylococcus aureus dengan daya hambat yang paling besar ditunjukkan pada konsentrasi $7 \%$ dengan diameter 5,75mm yang tergolong sedang. Sediaan masker gel peel-off tidak menunjukkan adanya daya hambat terhadap bakteri Staphylococcus aureus. 


\section{Daftar Pustaka}

Andaryekti, R., Mufrod, M., Munisih, S., 2015. Pengaruh Basis Gel Sediaan Masker Ekstrak Daun Teh Hijau (Camellia Sinensis Linn.) pada Karakteristik Fisik dan Aktivitas Bakteri Staphylococcus aureus ATCC 25923. Maj. Farm. 11, 294-299

Basuki, K.S., 2001. Tampil Cantik Dengan Perawatan Sendiri. Gramedia Pustaka Utama, Jakarta

Davis, W. W., and Stout, T. R. 1971. Disc Plate Method of Microbiological Antibiotic Assay. Applied Microbiology. 22 (4): 659-665

Edy, H.J., Marchaban, Wahyuono, S., Nugroho, A.E. 2016. Formulasi Dan Uji Sterilitas Hidrogel Herbal Ekstrak Etanol Daun Tagetes Erecta L. Pharmacon 5, 9-16

Edy, H.J., Marchaban, Wahyuono, S., Nugroho, A.E. 2017. Formulation And Evaluation Of Hydrogel Containing Tagetes erecta L. Leaves Etanolic Extract. International Journal of Current Innovation Research. 3 (3): 627-630

Edy, H.J., Parwanto M. L. E. 2019. PemanfaatanTanaman Tagetes erecta Linn. Dalam Kesehatan. Jurnal Biomedika Kesehatan 2(2):77-80 DOI https://doi.org/10.18051/JBiomedKes.2019.v 2.77-80

Syahrurachman, A., Chatim, A., Karuniawati, A., Santoso, A.U.S., 1994. Buku Ajar Mikrobiologi Kedokteran Edisi Revisi. Bin. Aksara, Jakarta

Yulianti, R., 2008. Pembuatan Minuman Jeli Daun Kelor (Moringa Oleifera Lam) Sebagai Sumber Vitamin C dan \s s-Karoten [skripsi]. Institut Pertanian, Bogor 